\title{
RESPON DUA VARIETAS BAWANG MERAH (Allium ascalonicum L.) DALAM MENINGKATKAN PRODUKSI DENGAN PEMBERIAN PUPUK KCL DI KECAMATAN RANTAU SELATAN
}

\author{
Fitra Syawal Harahap ${ }^{1}$, Hilwa Walida ${ }^{1}$, Rosmidah Hasibuan ${ }^{2}$, \\ Simon Haholongan Sidabuke
}

1.Program Studi Agroteknologi, Fakultas Sains dan Teknologi Universitas Labuhanbatu, Sumatera Utara 2.Program Studi Pendidikan Biologi Fakultas Keguruan dan Ilmu Pendidikan

Universitas Labuhanbatu 3.Program Studi Manajemen Kehutanan Fakultas Pertanian Universitas Simalungun 21142

E-mail: fitrasyawalharahap@gmail.com

\begin{abstract}
The decline in productivity of shallots (Allium ascalonicum L.) is one of the horticultural crops that are consumed by many Indonesian people, therefore it is necessary to provide potassium elements on the onion crop. Where potassium in plants is very important, it plays a role as a factor in the enzymes in the process of plant metabolism, stomata regulation, and $\mathrm{CO}$ assimilation. Meanwhile, if the lack of potassium causes small tubers so that production decreases. This study aims to determine the response of growth and yield of onion (Allium ascalonicum L.) to several varieties and dosages of KCL fertilizer. This research was conducted in the experimental area of the Faculty of Science and Technology of Labuhabatu University, South Rantau District with a height of 13 meters above sea level. The materials used in this study were Sumenep and Maja Cipanas Shallot Seed Varieties, Urea Fertilizer, TSP and KCl. The tools used in this study are the Global Positioning System (GPS), hoe, fat, meter, sample traces, scales, ovens and stationery that support this research. This research uses factorial randomized block design with 2 factors and 3 replications, namely: Factor 1: $V 1$ = Variety of Sumenep and V2 = Maja Cipanas and Factor 2 of fertilizer dose P0 ,, Control, $P 1=50 \mathrm{gram} /$ plot, $P 2=100 \mathrm{gram} / \mathrm{plot}, P 3=150 \mathrm{gram} / \mathrm{plot})$. The parameters observed were sample wet weight, plot dry weight, and the number of plot production. Research Results Showing the dosage treatment gave an effect on the growth and production of shallots with the best dose of 150 grams/plot. An interaction occurred between KCL fertilizer dosage and onion varieties on plant height, number of leaves, number of tubers, wet weight, number of production and dry weight of onion plants.
\end{abstract}

Keywords: Shallot, KCL Fertilizer, Production Results, Rantau Selatan District

\section{PENDAHULUAN}

\subsection{Latar Belakang}

Provinsi Sumatera Utara pada tahun 2015 menurut Dinas Pertanian yang kutip dari BPS (2015) Produksi Bawang merah adalah 9.971 ton per hektar dengan produktivitas 8.05 ton per hektar. Bawang merah (Allium ascalonicum L.) menjadi komoditas tanaman hortikultura yang sering dikonsumsi masyarakat (Suriani,2011). Menurunnya produktivitas sebesar 1,41 ton/ ha dan luasan panen menurun sebesar 13 hektar dibandingkan tahun 2014 disebabkan oleh menurunnya produktivitas. Dari data tersebut produktivitas bawang merah di kecamatan 
Payung di tahun 2014 lebih tinggi dibandingkan dengantahun 2015 (Irawan et al.,2004). Hasil Penlitian Luta et al., (2020), Aplikasi pembenah tanah mampu meningkatkan $\mathrm{pH}$, C-Organik, KTK dan N-Total tanah. Pembenah tanah yang terbaik pada penelitian ini adalah kompos sampah kota dengan dosis $2 \mathrm{~kg}-\mathrm{m}-2$. Hasil produksi bawang merah yang tinggi dapat diperoleh dari adanya interaksi antara tanaman dan lingkungannya, teknologi dan masalah sosial-ekonomi produsen (Antonio.2010). Salah satu unsur hara yang tergolong dalam unsur hara makro utama yang diperlukan untuk pertumbuhan tanaman adalah kalium (Setyorini,2003). Sebagai mengaktifkan enzim, mempertinggi daya tahan terhadap kekeringan, penyakit, dan perkembangan akar, pembentukan pati, dalam unsur kalium (K) berfungsi (Damanik, 2011).

Tisdale et al., (1990) dan Omar dan Kobbia (1996) melaporkan bahwa 14.5 $\mathrm{mg} / \mathrm{kg} \mathrm{K}$ dalam larutan keseimbangan sudah cukup untuk mendapatkan hasil tertinggi tanaman yang banyak membutuhkan K Kalium dalam tanaman sangat penting yaitu berperan sebagai faktor enzim dalam proses metabolism tanaman, regulasi stomata dan asimilasi CO. Kekurangan kalium menyebabkan umbi kecil sehingga produksi menurun (Tjionger, 2010).
Penggunaan pupuk KCL dan bokashi pada tanaman ubi jalar (Ipomae batatas) pada Pupuk $\mathrm{KCl}$ berpengaruh nyata terhadap jumlah umbi per tanaman, bobot umbi per umbi, berat umbi per tanaman dan berat brangkasan kering dengan perlakuan terbaik $15 \mathrm{~g}$ dan $\mathrm{KCl}$.( Sianturi, D.A et al., 2017). Rahmianna dan Bel (2001) menjelaskan bahwa pertumbuhan tanaman berkolerasi dengan penambahan konsentrasi kalium pada daerah pembesaran. Bila tanaman kekurangan kalium pada daerah pembesaran dan perpanjangan sel terhambat, akan mempengaruhi pertumbuhan tanaman. Kurangnya hara $\mathrm{K}$ dalam tanaman dapat menghambat proses transportasi dalam tanaman. Oleh karena itu, agar proses transportasi unsur hara maupun asimilat dalam tanaman dapat berlangsung optimal maka unsur $\mathrm{K}$ dalam tanaman harus optimal (Taufiq, 2002). Hasil Penelitian Silahooy, C.(2008), Efek Pupuk KCl dan SP-36 Terhadap Kalium Tersedia, Serapan Kalium dan Hasil Kacang Tanah (Arachis hypogaea L.), pada Tanah Brunize pada Kalium tersedia (Kdd) $0.26 \mathrm{me} / 100 \mathrm{~g}$ dan $4.95 \%$ serapan Kalium pada tanaman kacang tanah dicapai pada perlakuan $1.0 \mathrm{~g} \mathrm{KCl} /$ pot. Pengaruh pemberian pupuk KCL terhadap N,P,K tanah dan serapan tanaman pada inceptisol untuk tanaman jagung di Situ Hilir, Cibung Bulang, Bogor dengan 
Pemberian pupuk $\mathrm{KCl}$ pada berbagai taraf dosis berpengaruh nyata terhadap pertumbuhan tinggi tanaman dan jumlah daun tanaman jagung.

Pemberian pupuk KCl Rusia pada perlakuan P2-P7 secara nyata dapat meningkatkan hasil pipilan jagung dan bobot brangkasan (biomas) jagung dibandingkan dengan perlakuan tanpa perlakuan. (Fi'liyah, F et al., 2017). Amisnaipa (2009) menjelaskan bahwa pemberian dosis pupuk $\mathrm{KCl} 150.33 \mathrm{~kg} / \mathrm{ha}$ meningkatkan pengaruh perlakuan pupuk $\mathrm{K}$ terhadap tinggi tanaman, diameter batang, bobot segar biomassa dan bobot kering tanaman tomat.

Pengaruh pemberianPupuk $\mathrm{kcl}$ terhadap pertumbuhan dan hasil kedelai (glycine max 1.) yang diberikan saat tanaman mulai berbunga dengan Dosis pemberian pupuk $\mathrm{KCl}$ berpengaruh terhadap jumlah cabang, dan komponen hasil (jumlah polong pertanaman, jumlah polong berisi pertanaman, berat biji kering pertanaman, berat 100 biji dan hasil perhektar). Pertumbuhan terbaik dan hasil tertinggi diperoleh dari pemberian pupuk $\mathrm{KCl}$ pada dosis $100 \mathrm{~kg} / \mathrm{ha}$. Hasil Penelitian Sebayang et al., (2015), Aplikasi Pupuk $\mathrm{KCl}$ dan Pupuk Kandang Ayam Terhadap Ketersediaan dan Serapan Kalium Serta Pertumbuhan Tanaman Jagung (Zea mays L.) Pada Tanah Inseptisol Kwala Bekala dengan Perlakuan pupuk $\mathrm{KCl}$ tidak meningkatkan $\mathrm{K}$ tanah, Perlakuan pupuk $\mathrm{KCl}$ meningkatkan tinggi tanaman, bobot kering akar dan bobot kering Sumenep tanaman jagung berturutturut pada dosis $100 \mathrm{~kg} / \mathrm{ha}$ dan $150 \mathrm{~kg} / \mathrm{ha}$. Menurut Corey (1973), hara K yang diserap tanaman melalui proses diffusi sekitar $76 \%$ sedang yang melalui proses aliran massa sekitar 26\%. Pemupukan P,K dan waktu pemberian pupuk $\mathrm{K}$ pada tanaman ubikayu di lahan kering vertisol dengan pemupukan $100 \mathrm{~kg} \mathrm{KCl} / \mathrm{ha}$ dapat meningkatkan serapan hara $\mathrm{K}$ hingga mencapai $74 \%$ bila diberikan bersama pupuk $\mathrm{P}$ dengan dosis $75 \mathrm{~kg}$ SP36/ha, tetapi tidak jelas pengaruhnya terhadap peningkatan komponen hasil dan hasil umbi (Ispandi, A., 2003).

Respon pemberian dosis pupuk KCL dan dosis pupuk kandang sapi terhadap pertumbuhan bibit tanaman gaharu (aquilaria crassna) di polibag dengan Pemberian pupuk KCL menunjukkan berpengaruh tidak nyata terhadap tinggi tanaman umur 2, 4 dan 6 MST dan berpengaruh nyata pada umur 8 MST serta berpengaruh nyata terhadap jumlah helai daun pada umur 8 MST, serta berpengaruh tidak nyata pada luas helai daun dan diameter batang. (Ningsih, S.S. et al., 2017).Pupuk kalium dalam bentuk $\mathrm{KCl}$ dapat membantu memperkuat jaringan tanaman serta mempertebal dinding sel epidermis sehingga mampu meningkatkan 
ketahanan tanaman terhadap serangan patogen secara mekanis (Nurhayati, 2008).

Dari uraian di atas, maka penulis tertarik untuk melakukan kajian mengenai respon dua varietas bawang merah untuk meningkatkan hasil produksi dengan pemberian pupuk KCL di Kecamatan Rantau Selatan.

\subsection{Tujuan Penelitian}

Untuk mengetahui respon dua varietas bawang merah (Allium ascalonicum L.) untuk meningkatkan hasil produksi dengan pemberian pupuk KCL.

\section{BAHAN DAN METODE}

Penelitian ini dilakuan dilahan percobaan Fakultas Sains dan Teknologi Universitas Labuhabatu Kecamatan Rantau Selatan dengan ketinggian 13 meter diatas permukaan laut. Bahan yang digunakan dalam penelitian ini adalah Benih Bawang Merah Varietas Sumenep dan Maja Cipanas, Pupuk Urea, TSP dan $\mathrm{KCl}$. Alat yang digunakan dalam penelitian ini adalah Global positioning system (GPS), cangkul, gembor, meteran, pacak sampel, timbangan, oven serta alat tulis yang medukung penelitian ini. Penelitian ini menggunakan rancangan acak kelompok s(RAK) factorial dengan 2 Faktor dan 3 ulangan yakni : Faktor 1 : V1 $=$ Varietas Sumenep dan V2 = Maja
Cipanas dan Faktor 2 dosis pupuk $\mathrm{P}_{0}$, , Kontrol, $\mathrm{P}_{1=} 50$ gram $/$ plot, $\mathrm{P}_{2}=100$ gram/plot, $P_{3}=150$ gram/plot). Parameter yang diamati bobot basah persampel, bobot kering perplot, dan jumlah produksi perplot.

\section{HASIL DAN PEMBAHASAN}

Hasil respon dua varietas bawang merah untuk meningkatkan hasil produksi dengan pemberian pupuk KCL di kecamatan rantau selatan disajikan pada Tabel 1. Uji beda rataan bobot basah bawang merah dengan Penggunaan beberapa varietas bawang merah dan dosis pupuk $\mathrm{KCl}$ Dari hasil Tabel 1. Berdasarkan hasil pengamatan interaksi bobot basah(gram) bahwa penggunaan dosis pupuk KCL berpengaruh sangat nyata terhadap beberapa varietas bawang merah yang digunakan. Dimana bobot basah tertinggi terdapat pada perlakuan dosis pupuk $\mathrm{KCl}\left(\mathrm{V}_{1} \mathrm{P}_{3}\right)$ dengan Varietas Maja Cipanas sebesar 270 gram/sampel. Dari Tabel 1. Diatas dapat dilihat bahwa pengaruh dosis pupuk KCL berpengaruhnyata terhadap bobot basah pada Varietas Sumenep. Bobot basah tertinggi terdapat pada perlakuan $\mathrm{V}_{1} \mathrm{P}_{3}$ dengan bobot basah sebesar 170 gr/sampel, sedangkan bobot basah terendah terdapat pada perlakuan $\mathrm{V}_{2} \mathrm{P}_{0}$ (varietasi Maja Cipanas) tanpa penggunaan pupuk KCL 
sebesar $210 \mathrm{gr} / \mathrm{sampel}$. Penggunaan dosis $\mathrm{KCl}$ sebesar 150 gr/plot memberikann pengaruh yang nyata terhadap jumlah umbi bawang merah. Jumlah umbi tertinggi terdapat pada varietas Sumenep $\left(\mathrm{V}_{1} \mathrm{P}_{3}\right)$. Menurut Napitupulu dan Winarto, 2010 menyatakan dosis pupuk kalium yang diberikan untuk bawang merah umumnya antara $50-150 \quad \mathrm{~kg} / \mathrm{ha} \quad \mathrm{K}_{2} \mathrm{O}$. Liptan BPTP Jawa Barat teknik budidaya bawang merah dengan dosis $\mathrm{kg} / \mathrm{ha}$ pupuk $\mathrm{KCl}$ mampu meningkatkan kuantitas dan kualitas hasil bobot umbi kering dari bawang merah

Grafik jumlah produksi per plot dengan perlakuan jumlah dosis KCL terhadap jenis varietas yang digunakan dapat dilihat pada gambar 1 dibawah ini Dari Gambar 1. Pada grafik 1 dengan persamaan regresi $\mathrm{y}=0,13 \mathrm{x}+233 \mathrm{R}^{2}=$ 0,965 memperlihatkan bahwa pemberian pupuk $\mathrm{K}$ memberikan pengaruh nyata dalam meningkatkan hasil bawang merah.

Tabel 1. Rataan bobot basah (gram) bawang merah dengan beberapa varietas dan dosis Pupuk $\mathrm{KCl}$

\begin{tabular}{lccc}
\hline \multirow{2}{*}{ Dosis KCl } & \multicolumn{2}{c}{ JenisVarietas } & \multirow{2}{*}{ Rataan } \\
\cline { 2 - 3 } & V1 (Sumenep) & V2 (Maja Cipanas) & \\
\hline P0 (kontrol) & $130 \mathrm{~b}$ & $150 \mathrm{~d}$ & $140 \mathrm{c}$ \\
P1 (100 Gr/plot) & $150 \mathrm{ab}$ & $180 \mathrm{~d}$ & $165 \mathrm{~b}$ \\
P2 (200 gr/plot) & $160 \mathrm{a}$ & $200 \mathrm{a}$ & $180 \mathrm{a}$ \\
P3 (150 gr/plot) & $170 \mathrm{a}$ & $210 \mathrm{a}$ & $190 \mathrm{a}$ \\
\hline Rataan & $152.50 \mathrm{a}$ & $1485 \mathrm{~b}$ & \\
\hline
\end{tabular}

Keterangan : Angka yang diikuti oleh huruf yang tidak sama pada perlakuan yang sama berbeda nyata pada taraf $5 \%$

Hal ini menunjukkan bahwa pemberian pupuk $\mathrm{K}$ dengan dosis tinggi (150 gram/plot) mampu meningkatkan produksi bawang merah. Sedangkan grafik bobot kering per plot $(\mathrm{kg})$ Bawang merah dengan perlakuan jumlah dosis KCL terhadap jenis varietas yang digunakan dapa tdilihat pada Gambar 2 dibawah ini Dari Grafik 2 dengan persamaan regresi $\mathrm{y}=0,4 \mathrm{x}+155 \mathrm{R}^{2}=$ $0,952 *$ memperlihatkan bahwa pemberian pupuk $\mathrm{K}$ memberikan pengaruh nyata dalam meningkatkan hasil bawang merah.
Hal ini menunjukkan bahwa pemberian pupuk $\mathrm{K}$ dengan dosis tinggi (150 gram/plot) mampu meningkatkan produksi bawang merah (bobot kering). Hal ini disebabkan pupuk $\mathrm{KCl}$ meningkatkan KTK tanah unsur hara yang diserap tanaman berpengaruh terhadap jumlah Bobot pertanaman. Rahmianna, A.A. et al.,(2015), menyatakan bahwa unsur hara yang tersedia dalam keadaan cukup sesuai dengan kebutuhan tanaman maka dapat meningkatkan hasil tanaman. 


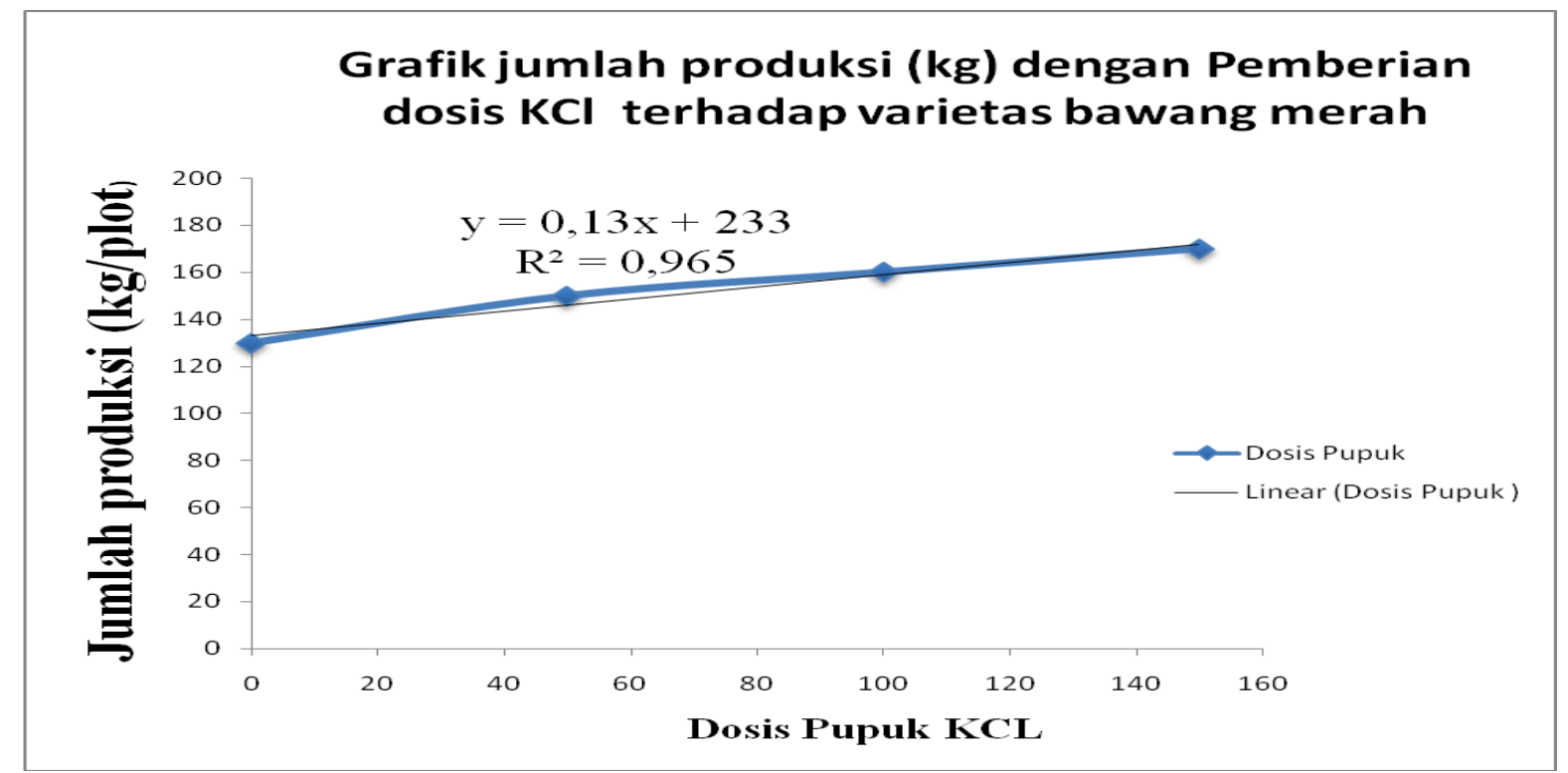

Gambar 1. Grafik jumlah produksi $(\mathrm{kg})$ dengan perlakuan jumlah dosis $\mathrm{KCl}$ terhadap varietas bawang merah

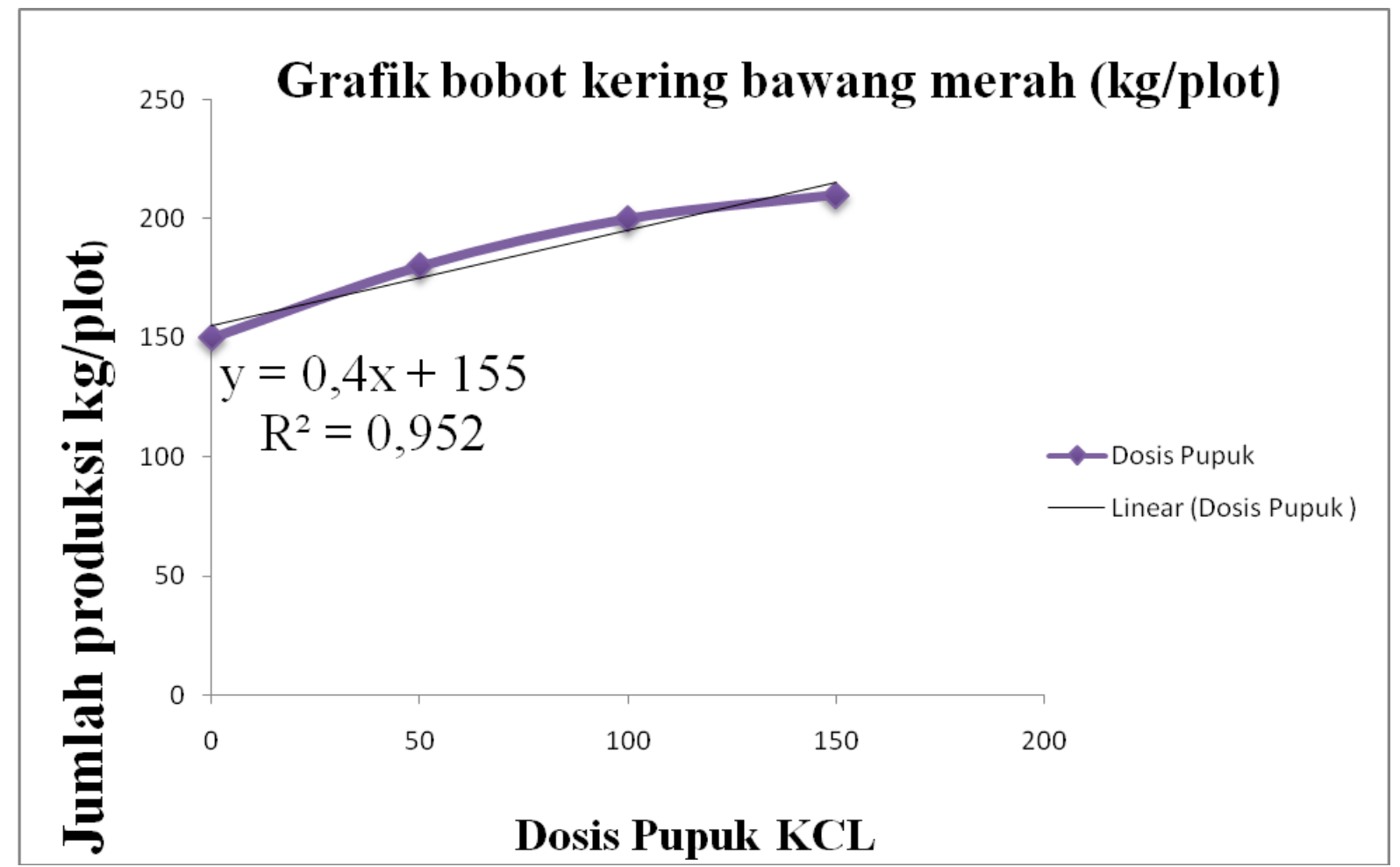

Gambar 2. Grafik bobot kering bawang merah (kg/plot)

\section{KESIMPULAN}

Pemberian dosis memberikan pengaruhnya terhadap pertumbuhan serta produski bawang merah dengan dosis 150 gram/plot sehingga terjadi interaksi antara dosis pupuk KL dan Varietas bawang terhadap tinggi tanaman, jumlah daun, jumlah umbi, bobot basa, jumlah produksi serta bobot tanaman kering 


\section{DAFTAR PUSTAKA}

[Kementan]. KementerianPertanian. 2016. Lampiran Keputusan Menteri Pertanian Nomor 045/Kpts/SR.120/D.2.7/5/2016. Jakarta (ID) :Kementerian Pertanian.

Amisnaipa. (2009). Penentuan Kebutuhan Pupuk Kalium untuk Budidaya Tomat Menggunakan Irigasi Tetes dan Mulsa Polyethylene. Institut Pertanian Bogor.

Antonio, M. 2010. Pertumbuhan dan Produksi Beberapa Varietas Bawang Merah (Allium ascalonicum L.) Terhadap Pupuk Majemuk NPK Dalam Berbagai Taraf.

Corey R.B. 1973. Factor Affacting the Availability of Nutrient to Plant, p 23-33. Dalam: L.M. Wals and J.D.Beaton (ed.) Soil Testing and Plant Analysis Soil.Sci.Soc. Am., Inc., Madison. USA.

Damanik, MMB; B.E hasibuan; Fauzi; Sarifuddin; Hamidah,H. 2011 Kesuburan Tanah dan Pemupukan.

Fi'liyah, F., Nurjaya, N. and Syekhfani, S., 2017. Pengaruh pemberian pupuk $\mathrm{KCl}$ terhadap $\mathrm{N}, \mathrm{P}, \mathrm{K}$ tanah dan serapan tanaman pada Inceptisol untuk tanaman jagung di Situ Hilir, Cibungbulang, Bogor. Jurnal Tanah dan Sumberdaya Lahan, 3(2), pp.329-337.

Irawan B. Kusmoro J. Arifin, Z. 2004. Keanekaragaman dan Kekerabatan Kultivar Bawang Merah Di Jawa Barat. J. Biotika3 (2) : 36-43.
Ispandi, A., 2003. Pemupukan P, K dan waktu pemberian pupuk $\mathrm{k}$ pada tanaman Ubikayu di lahan kering vertisol $\mathrm{P}$, $\mathrm{K}$ fertilization and frequency of $\mathrm{K}$ fertilizer application on cassava in vertisol upland. Ilmu Pertanian, 10(2), pp.35-50.

Luta, D.A., Siregar, M., Sabrina, T. and Harahap, F.S., 2020. Peran Aplikasi Pembenah Tanah Terhadap Sifat Kimia Tanah Pada Tanaman Bawang Merah. Jurnal Tanah dan Sumberdaya Lahan, 7(1), pp.121-125.

Ningsih, S.S. and Siagian, H.H., 2017. Respon Pemberian Dosis Pupuk Kcl Dan Dosis Pupuk Kandang Sapi Terhadap Pertumbuhan Bibit Tanaman Gaharu (Aquilaria crassna) di polibag. Bernas, 13(1), pp.3742.

Rahmianna, A.A., M. Bel. 2001. Telaah faktor pembatas kacang tanah. Penelitian Palawija. 5(1) : 6576.

Rahmianna, A.A., Pratiwi, H. and Harnowo, D., 2015. Budidaya kacang tanah. Monogr. Balitkabi; Kacang Tanah Inov. Teknol. dan Pengemb. Prod, 13(13), pp.134-169.

Sebayang, A.M., Damanik, M.M.B. and Lubis, K.S., 2015. Aplikasi Pupuk $\mathrm{KCl}$ dan Pupuk Kandang Ayam Terhadap Ketersediaan dan Serapan Kalium Serta PertumbuhanTanaman Jagung (Zea mays L.) Pada Tanah Inseptisol Kwala Bekala. Jurnal Agroekoteknologi Universitas Sumatera Utara, 3(3), p.104983. 
Setyorini, D. dan Prihatini, T. 2003. Menuju "quality control" pupuk organik di Indonesia. Disampaikan dalam Pertemuan Persiapan Penyusunan Persyaratan Minimal Pupuk Organik di Dit. Pupuk dan Pestisida, Ditjen Bina Sarana Pertanian, Jakarta.

Sianturi, D.A. and Ernita, E., 2017. Penggunaan Pupuk Kcl Dan Bokashi Pada Tanaman Ubi Jalar (Ipomae Batatas). Dinamika

Pertanian, 29(1), pp.37-44.

Silahooy, C., 2008. Efek pupuk $\mathrm{KCl}$ dan SP-36 terhadap kalium tersedia, serapan kalium dan hasil kacang tanah (Arachis hypogaea L.) pada tanah brunizem. Jurnal Agronomi Indonesia (Indonesian Journal of Agronomy), 36(2).

Suhartono, A.A. Syarief, 2002. Penampilan beberapa galur dan varietas kacang tanah pada lahan kering masam. Risallah Seminar Balittan. 1: 120-127. Sukarami, Sumatera Barat.

Suriani, N. 2011. Bawang Bawa Untung. Budidaya Bawang Merah dan Bawang Putih. Cahaya Atma Pustaka. Yogjakarta.

Taufiq, A. 2002. Status $\mathrm{P}$ dan K lahan kering tanah alfisol pulau Jawa dan Madura serta optimasi pemupukannya untuk tanaman kacang tanah. Prosiding Seminar Nasional dan Pertemuan Tahunan Komisariat Daerah Himpunan Ilmu Tanah Indonesia. 16-17 Desember 2002. Hal. 94-103. Malang.
Tjionger, M. 2010. Memperbesar dan memperbanyak umbi bawang merah.Indonesian agriculture.http://obtrando.word press.com

Tisdale, S. L., W. L. Nelson, J. D. Beaton. 1990. Soil Fertility and Fertilizer Macmillan Pub. Co. New York. 00 p. 